\title{
RESEARCH
}

Open Access

\section{Paludification reduces black spruce growth rate but does not alter tree water use efficiency in Canadian boreal forested peatlands}

\author{
Joannie Beaulne $e^{1,2,3^{*}}$ D, Étienne Boucher ${ }^{1,2,4}$, Michelle Garneau ${ }^{1,2,3,4}$ and Gabriel Magnan ${ }^{1,2,3}$
}

\begin{abstract}
Background: Black spruce (Picea mariana (Mill.) BSP)-forested peatlands are widespread ecosystems in boreal North America in which peat accumulation, known as the paludification process, has been shown to induce forest growth decline. The continuously evolving environmental conditions (e.g., water table rise, increasing peat thickness) in paludified forests may require tree growth mechanism adjustments over time. In this study, we investigate tree ecophysiological mechanisms along a paludification gradient in a boreal forested peatland of eastern Canada by combining peat-based and tree-ring analyses. Carbon and oxygen stable isotopes in tree rings are used to document changes in carbon assimilation rates, stomatal conductance, and water use efficiency. In addition, paleohydrological analyses are performed to evaluate the dynamical ecophysiological adjustments of black spruce trees to site-specific water table variations.

Results: Increasing peat accumulation considerably impacts forest growth, but no significant differences in tree water use efficiency (iWUE) are found between the study sites. Tree-ring isotopic analysis indicates no iWUE decrease over the last 100 years, but rather an important increase at each site up to the 1980s, before iWUE stabilized. Surprisingly, inferred basal area increments do not reflect such trends. Therefore, iWUE variations do not reflect tree ecophysiological adjustments required by changes in growing conditions. Local water table variations induce no changes in ecophysiological mechanisms, but a synchronous shift in iWUE is observed at all sites in the mid-1980s.

Conclusions: Our study shows that paludification induces black spruce growth decline without altering tree water use efficiency in boreal forested peatlands. These findings highlight that failing to account for paludification-related carbon use and allocation could result in the overestimation of aboveground biomass production in paludified sites. Further research on carbon allocation strategies is of utmost importance to understand the carbon sink capacity of these widespread ecosystems in the context of climate change, and to make appropriate forest management decisions in the boreal biome.
\end{abstract}

Keywords: Black spruce growth, Boreal biome, Carbon allocation, Ecophysiological mechanisms, Forested peatland, Paludification, Stable isotope, Water use efficiency

\footnotetext{
* Correspondence: joannie.beaulne@gmail.com

'Geotop Research Center, Université du Québec à Montréal, Montréal,

Québec H3C 3P8, Canada

²Department of Geography, Université du Québec à Montréal, Montréal,

Québec H3C 3P8, Canada

Full list of author information is available at the end of the article
}

\section{Springer Open}

(๑) The Author(s). 2021 Open Access This article is licensed under a Creative Commons Attribution 4.0 International License, which permits use, sharing, adaptation, distribution and reproduction in any medium or format, as long as you give appropriate credit to the original author(s) and the source, provide a link to the Creative Commons licence, and indicate if changes were made. The images or other third party material in this article are included in the article's Creative Commons licence, unless indicated otherwise in a credit line to the material. If material is not included in the article's Creative Commons licence and your intended use is not permitted by statutory regulation or exceeds the permitted use, you will need to obtain permission directly from the copyright holder. To view a copy of this licence, visit http://creativecommons.org/licenses/by/4.0/. 


\section{Background}

Black-spruce (Picea mariana (Mill.) BSP)-dominated forested peatlands are widespread ecosystems in boreal North America (Korhola 1995; Crawford et al. 2003; Lavoie et al. 2005). In such environments, Sphagnum moss growth is favored and leads to the development of thick organic layers that maintain cool, acid, humid, and anaerobic soil conditions (van Cleve et al. 1983; Fenton and Bergeron 2006). As this paludification process progresses, soil temperature and nutrients become limiting, and forest growth eventually declines (Boudreault et al. 2002; Harper et al. 2003; Simard et al. 2007; Lafleur et al. 2011), leading to tree dieback and an opening of forest stands. This negatively impacts the forest productivity and, therefore, several management practices have been developed to reduce or even reverse this process (e.g., Lavoie et al. 2005; Bergeron et al. 2007; Fenton et al. 2009). However, in order to enhance our capacity to anticipate the effects of paludification on forest productivity, there is a need to shed light on the ecophysiological mechanisms that control forest growth decline in paludified ecosystems.

Based on existing ecophysiological theory (mostly developed in non-paludified sites), three mechanisms may possibly be invoked either jointly or separately to explain such declines in black spruce growth. First, paludification process may reduce carbon assimilation rates $(A)$, as it is well known that the photosynthesis apparatus of plants is sensitive to thermal (Göbel et al. 2019), oxygen (Bartholomeus et al. 2008) or nutrient limitations (Longstreth and Nobel 1980). A reduction in $A$ would imply the downregulation of gross primary production (GPP) and less photosynthates export to stem growth. In temperate environments, such a positive relationship between GPP and stem growth has been elucidated (Belmecheri et al. 2014), but this relationship is far from being applicable to boreal and paludified forests. In boreal environments, relationships between carbon uptake and forest growth are either inconclusive (Rocha et al. 2006) or decoupled (Pappas et al. 2020), while remaining unexplored in paludified ecosystems. Second, growth decline could also result from a reduction of stomatal conductance $\left(g_{\mathrm{s}}\right)$. When trees are severely affected by drought stress, stomatal closure allows plants to reduce water losses during transpiration, but this mechanism also penalizes carbon uptake and ultimately results in lower growth rates (Linares and Camarero 2012). However, in paludified environments, adjustments of plant stomata to peat accumulation, climate variability, and water table variations are yet to be determined. Lastly, trees growing in nutrient-poor/low oxygen settings are more susceptible to allocate carbon to the root system rather than to aboveground components (Giardina et al. 2003; Vicca et al. 2012). Thus, changes in carbon allocation strategies favoring belowground biomass as peat accumulates could explain the apparent growth decrease visible in stems.

Another source of uncertainty arises from the fact that trees growing in paludified ecosystems deal with continuously evolving environmental conditions. The accumulation of thick organic layers induces significant changes that highlight the dynamic interactions occurring in boreal forested peatlands. For example, paludification is characterized by water table rise (Lavoie et al. 2005; Fenton and Bergeron 2006), and interactions over time may exist between water table fluctuations, stem growth, and tree water use efficiency (i.e., the ratio of carbon assimilated to water losses through evapotranspiration; Farquhar et al. 1989). These interactions, which remain largely unexplored, may vary in function of the degree of paludification (i.e., organic layer thickness). Consequently, how ecophysiological mechanisms adjust to such changes and how they impact tree radial growth over time needs to be addressed.

Carbon and oxygen stable isotopes in tree-ring cellulose may be of great help to disentangle ecophysiological processes responsible for tree growth decline in paludified environments. Indeed, gas exchange dynamics at the leaf-atmosphere interface are imprinted in the isotopic signature of annually-produced wood. For example, both $A$ and $g_{\text {s }}$ affect carbon stable isotope fractionation in tree-ring cellulose (Scheidegger et al. 2000; Cernusak et al. 2013), and the ratio between both, namely intrinsic water use efficiency (iWUE $=A / g_{\mathrm{s}}$ ), is at the core of ecosystem functioning (Guerrieri et al. 2019). Moreover, fractionation of oxygen stable isotopes reflects the magnitude of stomatal controls (through $g_{\mathrm{s}}$ ) on transpiration jointly with the signal of source water uptake (Barbour 2007). Tree-ring based analysis of ${ }^{13} \mathrm{C}$ and ${ }^{18} \mathrm{O}$ can help tracking dynamical adjustments of ecophysiological parameters to changing environmental conditions (Voelker et al. 2016). Such strategies have been well studied for well-drained environments (Frank et al. 2015; Voelker et al. 2016), but have never been investigated for paludified sites. In addition, the use of a paleoecological approach may be useful to investigate the interactions between tree growth mechanisms and local environmental conditions in boreal forested peatlands. Analyses of peat cores are commonly used to document, among others, past changes in both vegetation composition and hydrological conditions. For example, testate amoeba (unicellular protists) shells preserved in peat are widely used proxies for reconstructing variations in water table depths (Mitchell et al. 2008). Such paleoecological and paleohydrological analyses have previously been conducted in forested peatlands (Ruppel et al. 2013; Le Stum-Boivin et al. 2019; Magnan et al. 2019), but have never been put in relation to tree growth. 
In this study, we investigate the mechanisms that drive tree growth decline in black-spruce-dominated forested peatlands of eastern Canada. To do this, we compare tree-ring-derived growth trends and stable-isotopeinferred ecophysiological processes along a paludification gradient characterized by increasingly thicker peat deposits. More specifically, the objectives of the study are to (1) determine whether the decline in stem growth induced by the paludification process is attributable to changes in ecophysiological processes (such as $A$ or $g_{\mathrm{s}}$ ) and/or to changes in carbon allocation strategies, and (2) evaluate the dynamical ecophysiological adjustments to ever-changing environmental conditions. We hypothesised that (1) growth decline results from a reduction of water use efficiency (iWUE), (2) reductions in iWUE are greater in the most paludified sites, and (3) strongest ecophysiological adaptation also take place in the most paludified sites. In order to test these hypotheses, we used an innovative approach that combines peat-based paleohydrological analyses - to reconstruct past variations in water table depth - and stable isotope analyses in tree rings - to investigate iWUE changes through time.

\section{Methods}

\section{Study area}

The study was conducted in the south of James Bay in eastern Canada, within the Clay Belt region which is part of the black spruce-feather moss bioclimatic domain
(Saucier et al. 2009; Fig. 1). This area is particularly prone to paludification due to the relatively cold and humid climate, the flat topography, and the dominance of poorlydrained clayey sediments left by the proglacial lakes Barlow and Ojibway (Vincent and Hardy 1977). Mean annual temperature is $0.3^{\circ} \mathrm{C}$ (over the $1950-2013$ period), ranging from $-18.9^{\circ} \mathrm{C}$ in January to $16.3^{\circ} \mathrm{C}$ in July, and mean annual precipitation is $818 \mathrm{~mm}$ (McKenney et al. 2011). The regional fire cycle is estimated at $\sim 400$ years since 1920 (Bergeron et al. 2004), allowing the accumulation of thick organic layers in forests between fire events.

\section{Site selection and sampling}

The Casa forested peatland $\left(49^{\circ} 33^{\prime} 06^{\prime \prime} \mathrm{N}, 78^{\circ} 59^{\prime} 10^{\prime \prime} \mathrm{W}\right.$; Fig. S2.1) was selected following the studies of Magnan et al. (2020) and Le Stum-Boivin et al. (2019) due to its regional representativeness in terms of topography, vegetation composition, and canopy openness. The slope is $<1 \%$ and the organic layer thickness varies between 40 $\mathrm{cm}$ and more than $1 \mathrm{~m}$ along the selected transect. The canopy cover is relatively closed but gradually opens up with organic layer thickening, which is typically observed in forested peatlands of the Clay Belt. The aboveground vegetation is largely dominated by black spruce and ericaceous shrubs, such as Vaccinium angustifolium Ait., Rhododendron groenlandicum (Oeder) Kron and Judd, Kalmia angustifolia L., and Chamaedaphne calyculata (L.) Moench. The understory is dominated by Sphagnum

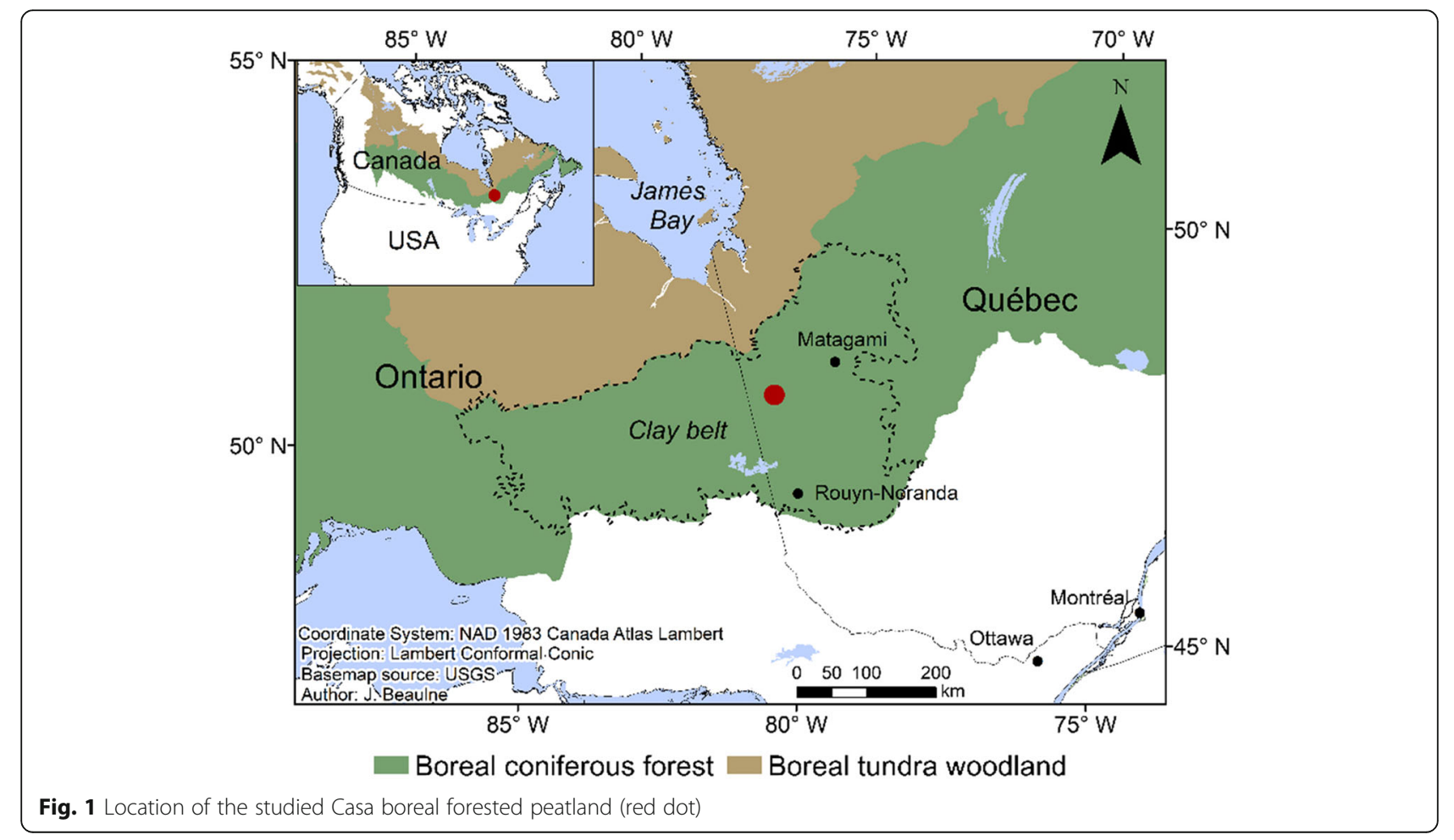


communities, particularly S. angustifolium (C. Jens. ex Russ.) C. Jens. and S. fallax (Klinggr.) Klinggr. under the tree canopy, and S. fuscum (Schimp.) Klinggr. where the canopy cover is more open.

Three sampling sites (CAS0, CAS50, CAS100) were established along a 100-m transect following an organic matter thickness gradient within the selected forested peatland (Fig. 2). At each site, one peat monolith was sampled down to the mineral contact using a Box corer (Jeglum et al. 1992). Sampling locations were chosen to be representative of the degree of paludification of each site in terms of peat thickness and canopy opening. Relative surface altitude and peat thickness were measured at 5-m intervals along the transect using a high precision altimeter (ZIPLEVEL PRO-2000) and an Oakfield probe. Water table depths were measured at the same intervals, in June 2017 and September 2018, a few hours after holes were dug to make sure that the water table level had stabilized. Twenty black spruce trees were also sampled at each site within a $10-\mathrm{m}$ radius of the collected peat core. Only dominant and codominant trees with straight stems and no visible scars were selected. Peat thickness was measured at the bottom of each sampled tree to validate the concordance with the mean peat thickness of the site. The diameter at breast height (DBH) and the height of selected trees were measured and cross-sections were collected at standard height (1.3 $\mathrm{m})$. The root system of one black spruce tree per site was excavated to verify the depth of the rooting zone and the growth substrate (i.e., mineral or organic matter). Moreover, tree aboveground biomass of each site was estimated by measuring the diameter at breast height $(\mathrm{DBH})$ of all trees $(\mathrm{DBH} \geq 1 \mathrm{~cm})$ within a $10 \mathrm{~m} \times$ $10 \mathrm{~m}$ plot and then using allometric equations adapted to black spruce growth (Ung et al. 2008).

\section{Black spruce radial growth analysis}

The 60 dried cross-sections were finely sanded (from 80 to 600 grit size) prior to ring-width measurements along two radii using CooRecorder software (version 8.1.1; Larson 2016). Samples were visually cross-dated using PAST5 software (version 5.0.610; Knibbe 2019), and skeleton plots were generated using the $\mathrm{R}$ package $d p l R$ (version 1.6.9; Bunn et al. 2018). Ring-width series were converted to annual basal area increment (BAI) to compare tree aboveground productivity between the three sites, as BAI is more representative of three-dimensional stem growth than the linear ring-width measurements (Husch et al. 2003; Biondi and Qeadan 2008). Individual BAI series were produced using the R package $d p l R$ (version 1.6.9; Bunn et al. 2018), and yearly averages were then calculated using all trees from the same site. Ringwidth series were also standardized (Fig. S2.7) in order to perform correlation analyses with climate data (Supplementary Material 1.1).

\section{Isotopic analysis of tree rings}

Black spruce ecophysiological processes were evaluated from carbon $\left(\delta^{13} \mathrm{C}\right)$ and oxygen $\left(\delta^{18} \mathrm{O}\right)$ isotopic ratio analyses. These were performed on five trees per site and from two wood strips per tree (i.e., a total of 30 samples). Sample preparation was carried out following the protocol described in Giguère-Croteau et al. (2019) (Supplementary Material 1.2). A five-year resolution over a 100 -year period (1919-2018) was considered. Alpha-cellulose was extracted, as suggested for black spruce samples (Bégin et al. 2015), following the protocol used by Naulier et al. (2014).

Tree-ring $\delta^{13} \mathrm{C}$ values vary according to discrimination against ${ }^{13} \mathrm{C}$ during photosynthesis, defined as (Farquhar et al. 1982):

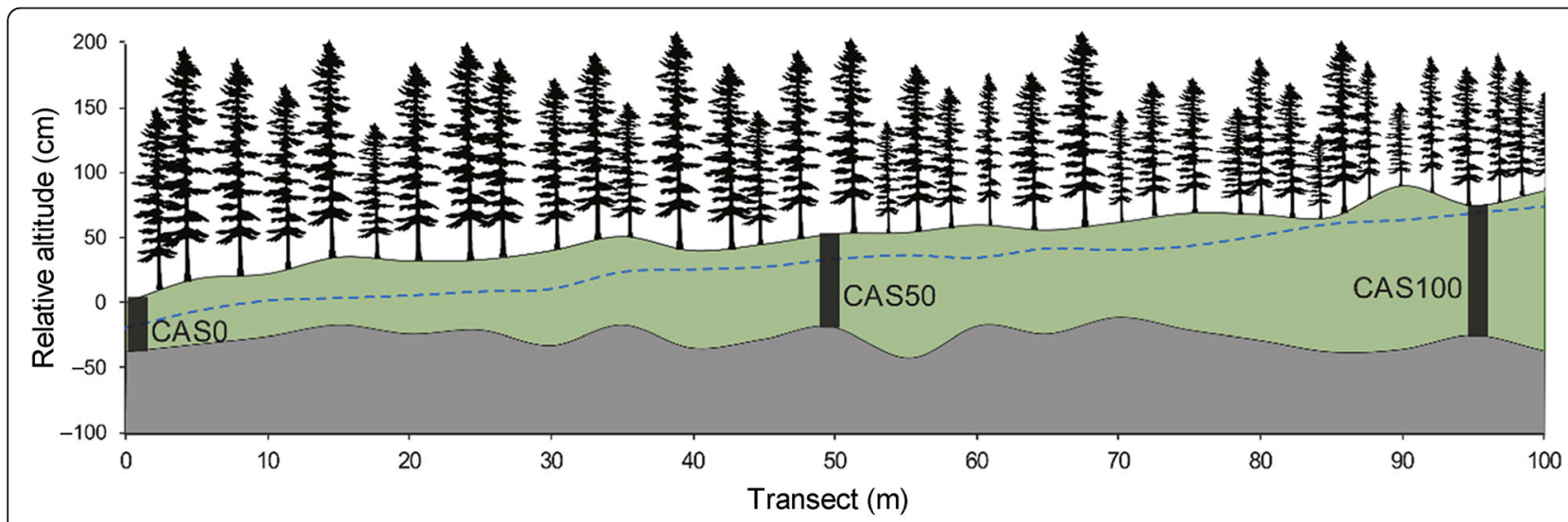

Fig. 2 Schematic representation of the three sites along the study transect. Relative altitude of the organic layer (green) and the mineral surface (grey) are shown. Black rectangles represent the location of the sampled peat cores. The dotted blue line indicates the depth of the water table measured in the field. Trees are not to scale but are representative of variations in canopy openness along the transect 


$$
\Delta^{13} \mathrm{C}=\frac{\delta^{13} C_{\text {air }}-\delta^{13} C_{\text {tree }}}{1+\left(\delta^{13} C_{\text {tree }} / 1000\right)},
$$

where $\delta^{13} \mathrm{C}_{\text {air }}$ is the carbon isotope ratio of the atmosphere and $\delta^{13} \mathrm{C}_{\text {tree }}$ is the isotopic value of the tree ring. $\delta^{13} C_{\text {air }}$ values were taken from McCarroll and Loader (2004) for the 1919-2003 period, and were linearly extrapolated for the 2004-2018 period. Because of the five-year resolution of $\delta^{13} \mathrm{C}_{\text {tree }}$ values, we averaged the $\delta^{13} C_{\text {air }}$ values over 5 y. Following Farquhar et al. (1989), $\Delta{ }^{13} \mathrm{C}$ is related to leaf intercellular $\mathrm{CO}_{2}$ concentration $\left(c_{\mathrm{i}}\right)$ and ambient $\mathrm{CO}_{2}$ concentration $\left(c_{\mathrm{a}}\right)$ according to the following equation:

$$
\Delta^{13} \mathrm{C}=a+(b-a)\left(\frac{c_{\mathrm{i}}}{c_{\mathrm{a}}}\right)
$$

where $a(4.4 \%)$ is the fractionation occurring during $\mathrm{CO}_{2}$ diffusion through stomata (O'Leary 1981) and $b$ (27\%) is the fractionation due to carboxylation by the Rubisco enzyme (Farquhar and Richards 1984). Values of $c_{\mathrm{a}}$ were obtained from the Mauna Loa Observatory (esrl.noaa.gov/gmd/ccgg/). Intrinsic water use efficiency (iWUE), defined as the amount of carbon assimilated per unit of water lost, can then be estimated from $c_{\mathrm{i}}$ and $c_{\mathrm{a}}$ as follows (Ehleringer et al. 1993):

$$
\mathrm{iWUE}=\left(\frac{A}{g_{\mathrm{s}}}\right)=\left(\frac{c_{\mathrm{a}}-c_{\mathrm{i}}}{1.6}\right),
$$

where $A$ is the rate of $\mathrm{CO}_{2}$ assimilation, $g_{\mathrm{s}}$ is the stomatal conductance, and the constant 1.6 represents the ratio of water vapor and $\mathrm{CO}_{2}$ diffusivity in air. Equation 3 shows that the difference between $c_{\mathrm{a}}$ and $c_{\mathrm{i}}$ is related to the ratio of assimilation $(A)$ to stomatal conductance $\left(g_{\mathrm{s}}\right)$.

Since the $\delta^{18} \mathrm{O}$ composition of tree rings is mainly controlled by leaf water composition and enrichment due to transpiration of lighter oxygen isotopes, $\delta^{18} \mathrm{O}$ values are assumed to be related to the stomatal conductance and independent of photosynthetic activity (Yakir 1992; Barbour 2007). Therefore, by combining $\delta^{13} \mathrm{C}$ and $\delta^{18} \mathrm{O}$ analyses it is possible to discriminate the effects of changes in photosynthetic rate $(A)$ and stomatal behavior $\left(g_{\mathrm{s}}\right)$ on iWUE (Scheidegger et al. 2000).

\section{Peat-based paleoecohydrological reconstructions}

In order to evaluate the response of black spruce ecophysiological mechanisms to hydrological variations, water table depths were reconstructed from peat core analyses. The collected cores were cut into $1 \mathrm{~cm}$-thick slices before analysing testate amoeba assemblages at 1$\mathrm{cm}$ intervals. Testate amoeba shells were extracted following the standard protocol of Booth et al. (2010) (Supplementary Material 1.3). Samples were then analysed under an optical microscope (400× magnification). A minimum of 100 tests was counted per sample, except in highly humified peat samples, in which test concentration was very low. In these cases, no water table depth (WTD) was inferred, as the total count $(<20$ tests) was insufficient to ensure reliable WTD reconstruction (Payne and Mitchell 2009). Past WTDs were reconstructed using a weighted average model with tolerance down-weighting and inverse deshrinking (WA.inv.tol). The transfer function was built using the R package rioja (version 0.9-15.1; Juggins 2017), from a modern dataset of 272 surface samples combining non-forested (Lamarre et al. 2013) and forested peatlands (Beaulne et al. 2018 and this study) of eastern Canada. High inferred WTD values corresponded to drier surface conditions.

Plant macrofossils and macroscopic charcoal particles $(>0.5 \mathrm{~mm})$ were also analysed along each peat core to reconstruct vegetation dynamics since peat initiation and better understand the paludification process at each site (Supplementary Material 1.4).

\section{Peat core chronologies}

A total of 11 samples were submitted to A. E. Lalonde AMS Laboratory (University of Ottawa, Canada) for accelerator mass spectrometry radiocarbon dating $\left({ }^{14} \mathrm{C}\right)$. Plant macrofossil remains were carefully selected to date peat initiation, the last fire event, and main transitions in vegetation composition at each sampling site (Beaulne et al. 2021). The ${ }^{14} \mathrm{C}$ dates were calibrated using the IntCal13 calibration curve (Reimer et al. 2013). ${ }^{210} \mathrm{~Pb}$ dating was also achieved for the uppermost $24-26 \mathrm{~cm}$ of peat cores at $1-\mathrm{cm}$ intervals by alpha spectrometry (EGG Ortec 476A) at the GEOTOP Research Center (Université du Québec à Montréal, Canada). Ages were inferred by ${ }^{210} \mathrm{~Pb}$ activity measurement, using the constant rate of supply model (Appleby and Oldfield 1978) following $\mathrm{HNO}_{3}-\mathrm{HCl}-\mathrm{H}_{2} \mathrm{O}_{2}$ sample digestion (Ali et al. 2008). Age-depth models were generated using the rbacon package in $\mathrm{R}$ (version 2.3.9.1; Blaauw and Christen 2019). Ages are expressed in calendar years before present (cal yr BP; $1950 \mathrm{CE}$ ) and the age of the peat surface is therefore set to $-67 \mathrm{cal}$ yr BP (coring year: 2017 $\mathrm{CE})$.

\section{Statistical analyses}

Statistical analyses were achieved to compare data in function of the degree of paludification. One-way ANOVA analyses were performed to test for differences in BAIs, WTDs, $\delta^{13} \mathrm{C}$-derived ecophysiological parameters, and tree-ring $\delta^{18} \mathrm{O}$ between sites. Post-hoc Tukey Honest Significant Difference (HSD) were performed to identify significant differences in the mean for each site. Breakpoints in slopes were also estimated from Davies 
test (Davies 1987) for $\delta^{13} \mathrm{C}$-derived ecophysiological parameters, tree-ring $\delta^{18} \mathrm{O}$, and WTDs. All statistical analyses were performed in R ( $\mathrm{R}$ Core Team 2018).

\section{Results}

The study sites CAS0, CAS50, and CAS100 have an organic layer thickness of 40,73, and $98 \mathrm{~cm}$, respectively (Table 1). Tree-ring analyses revealed even-aged stands covering the period 1839-2018 CE at each site (see sample depth in Fig. 3 for tree age variability). Radiocarbon dating of the most recent charcoal layer indicates that the last fire event occurred between 0 and $290 \mathrm{cal} \mathrm{yr} \mathrm{BP}$ (median age: 175-179 cal yr BP; Table S2.1). These results suggest that trees were from the first cohort that grew after the last local fire, which most likely occurred around $200-250$ years ago ( $1800 \mathrm{CE})$. The depth of the uppermost charcoal layer in the peat profile indicates that black spruce established in a residual organic layer of approximately 15,45 , and $65 \mathrm{~cm}$ at sites CASO, CAS50, and CAS100, respectively. The root system excavation of the three selected trees suggests that roots reached the mineral soil at CASO and CAS50, but were restricted to the organic layer at CAS100.

\section{Black spruce radial growth}

Tree height and DBH values decrease along the paludification gradient, with the lowest values observed at the most paludified site where the organic layers are the thickest (Table 1). Mean DBHs of 10.0, 9.1, and $5.6 \mathrm{~cm}$ were calculated for CAS0, CAS50, and CAS100, respectively. BAIs also indicate a significant decrease in stem growth rates with increasing peat thickness (Table 2; Fig. 3, Fig. S2.3). Trees from CAS0 added a greater wood surface with age, resulting in an increasing BAI trend (mean $\mathrm{BAI}=70 \mathrm{~mm}^{2}$ ). At CAS50, tree radial growth followed similar patterns but was more limited (mean BAI $=51 \mathrm{~mm}^{2}$ ). In contrast, trees from CAS100 maintained relatively constant BAI values, resulting in decreased wood production (mean BAI $=40 \mathrm{~mm}^{2}$ ). Estimates of tree aboveground biomass showed similar trends with values of $8.9,7.6$, and $4.6 \mathrm{~kg} \cdot \mathrm{m}^{-2}$ for sites CAS0, CAS50, and CAS100, respectively.

\section{Trends in $\delta^{13} \mathrm{C}, \delta^{18} \mathrm{O}$, and iWUE}

The $\delta^{13} \mathrm{C}$-derived ecophysiological parameters do not differ between the three sites over the 1919-2000 period (Fig. 4a, Table 2). Over time, black spruce trees used two different strategies in response to rising $c_{\mathrm{a}}$. A substantial increase in iWUE was first observed until the $1980 \mathrm{~s}\left(c_{\mathrm{a}} \approx 340 \mathrm{ppm}\right)$, along with relatively stable intercellular $\mathrm{CO}_{2}$ concentration $\left(c_{\mathrm{i}}\right)$. During this period, iWUE increased by $43 \%$ at each site. A major shift in tree ecophysiology then occurred in the mid-1980s as $c_{\mathrm{i}}$ began to increase considerably. In parallel, iWUE stabilized until 2018, except for at CASO, where a new increase seems to have begun around 2000. However, this recent trend at CASO should be interpreted with caution considering its short duration and the five-year resolution.

Tree-ring cellulose $\delta^{18} \mathrm{O}$ analyses show no significant trends for the three sites across the whole record (Fig. 4 b, Table 2). However, oxygen stable isotope ratios were systematically lower at the least paludified site (CAS0), suggesting a greater depletion in heavy isotopes. For all series, tree-ring $\delta^{18} \mathrm{O}$ values increased until $\sim 1950$ and became more constant afterwards, except for a slight decrease in the early 2000 s at CAS50.

\section{Paleoecohydrological reconstructions}

Both hydrological conditions and vegetation composition were similar between the three sites throughout the duration of black spruce growth (Figs. S2.4, S2.5). Macrofossil analysis showed that the last fire $(\sim 1800 \mathrm{CE})$ induced a shift in vegetation composition from high dominance of woody vegetation to a black spruce-Sphagnum-dominated stand (Fig. S2.4). The canopy opening allowed rapid Sphagnum moss expansion in the bryophyte layer while the black spruce post-fire cohort established.

Testate amoeba records indicate relatively wet conditions (high water table levels) shortly after the fire, followed by a gradual lowering of the water table at the three sites (Fig. 5a, Fig. S2.5). Inferred WTD values show very similar hydrological conditions at CAS50 and CAS100 during the post-fire period (1840-2017). Both sites had stable WTD between 15 and $20 \mathrm{~cm}$ before water tables deepened during the 2000s, particularly in

Table 1 Characteristics of the three study sites $^{a}$

\begin{tabular}{|c|c|c|c|c|c|c|c|}
\hline Site & $\begin{array}{l}\text { Mean organic } \\
\text { layer thickness } \\
\text { (cm) }\end{array}$ & $\begin{array}{l}\text { Core length } \\
(\mathrm{cm})\end{array}$ & $\begin{array}{l}\text { Mean WTD } \\
(\mathrm{cm})\end{array}$ & $\begin{array}{l}\text { Mean } \mathrm{DBH}^{\mathrm{b}} \\
(\mathrm{cm})\end{array}$ & $\begin{array}{l}\text { Tree } \\
\text { aboveground } \\
\text { biomass } \\
\left(\mathrm{kg} \cdot \mathrm{m}^{-2}\right)\end{array}$ & $\begin{array}{l}\text { Tree } \\
\text { density, } \\
\left(\text { trees }^{b} a^{-1} \text { ) }\right.\end{array}$ & $\begin{array}{l}\text { Mean tree } \\
\text { height }^{d}(m)\end{array}$ \\
\hline CASO & $40 \pm 5$ & 38 & $25 \pm 2$ & $10.0 \pm 1.6$ & $8.9 \pm 0.3$ & 1200 & $13.8 \pm 0.4$ \\
\hline CAS50 & $73 \pm 4$ & 69 & $20 \pm 1$ & $9.1 \pm 1.1$ & $7.6 \pm 0.3$ & 1200 & $11.3 \pm 0.5$ \\
\hline CAS100 & $98 \pm 4$ & 95 & $10 \pm 2$ & $5.6 \pm 0.8$ & $4.6 \pm 0.2$ & 1000 & $10.4 \pm 0.5$ \\
\hline
\end{tabular}

a values correspond to standard errors

${ }^{\mathrm{b}}$ Calculated from all trees $(\mathrm{DBH} \geq 1 \mathrm{~cm}$ ) within a $10 \mathrm{~m} \times 10 \mathrm{~m}$ plot, which includes 20,24 , and 34 trees for sites CAS0, CAS50, and CAS100 respectively

c Include trees with a diameter at breast height $(\mathrm{DBH}) \geq 9 \mathrm{~cm}$

${ }^{d}$ Calculated from the 20 black spruce trees (dominant and co-dominant) sampled at each site 


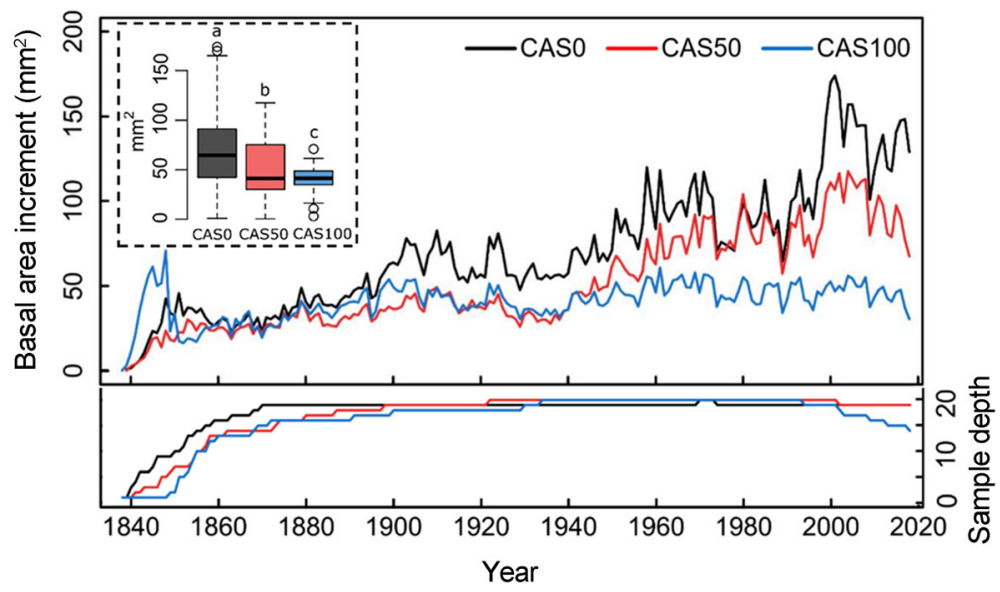

Fig. 3 Mean annual basal area increment of black spruce trees since their establishment after the last fire event. The decrease in sample depth (i.e., number of trees included in the chronologies) at CAS100 since 2000 is explained by some trees for which the latest rings were partly missing. See Fig. S2.3 for BAI distribution. Boxplots show the median, quartile range, extreme values (dotted lines), and outliers (dots) of the distribution. Different letters above the boxes indicate significant differences between the sites based on Tukey's HSD test

the very recent horizons $(\sim 2010)$, while the water table lowered more gradually at CASO. It remains unclear whether the apparent drying trend reflects increasingly drier surface conditions or simply an enhanced vertical growth of Sphagnum mosses that disconnected the peat surface from the water table. Indeed, warmer conditions observed since the 1990s (Fig. S2.6) have led to increasing growing degree days (Fig. $5 \mathrm{~b}$ ), which could have promoted this rapid peat accumulation.

\section{Discussion}

\section{Stem growth decoupled from iWUE variations}

Our study demonstrated that the paludification process considerably altered forest growth without influencing

Table 2 Results of one-way ANOVA analyses comparing the three study sites ${ }^{\mathrm{a}}$

\begin{tabular}{llll}
\hline \hline Variable & Degree of freedom & $\boldsymbol{F}$-value & $P$-value \\
\hline DBH & 78 & 11.20 & $<0.001$ \\
Tree height & 57 & 14.18 & $<0.001$ \\
WTD (present) & 9 & 10.23 & $<0.005$ \\
Organic layer thickness & 15 & 97.42 & $<0.001$ \\
$-\mathrm{BAl}$ & 537 & 53.97 & $<0.001$ \\
WTD (past) & 429 & 1.78 & 0.170 \\
$\delta^{13} \mathrm{C}$ & 57 & 0.408 & 0.667 \\
$C_{\mathrm{i}}$ & 57 & 0.232 & 0.794 \\
$C_{\mathrm{i}} / C_{a}$ & 57 & 0.408 & 0.667 \\
iWUE $^{18} \mathrm{O}$ & 57 & 0.160 & 0.853 \\
$\delta^{18}$ & 57 & 12.04 & $<0.001$ \\
\hline
\end{tabular}

${ }^{a}$ Above the dotted line are variables measured in the field whereas reconstructed variables (chronologies) are presented below the line the intrinsic water use efficiency of black spruce trees. Sites with the thickest organic matter accumulation were characterized by dominant trees that grew slower, presented smaller heights and diameters (DBH), and had a lower tree density comparatively to the least paludified site (Table 1; Fig. 3). These results are in agreement with previous studies that documented forest productivity decline with increasing peat accumulation in the black spruce feather moss domain of eastern Canada (Harper et al. 2003; Fenton et al. 2005; Lecomte et al. 2006; Simard et al. 2007). Surprisingly, however, our tree-ring stable isotope analysis indicates no iWUE decrease over the last 100 years at the three study sites, but rather a substantial increase up to the 1980s (Fig. 4a).

The stable isotope analysis revealed that $\delta^{13} \mathrm{C}$-derived parameters are not statistically different in all sites (Table 2), both in terms of average iWUE levels and temporal variations, suggesting that the ratio of assimilation rates to stomatal conductance is unaltered by the degree of paludification. We thereby also refute our second research hypothesis. In order to maintain comparable iWUE values across the paludification gradient (both in terms of mean and variability), the proportionality of the $A / g_{\mathrm{s}}$ ratio needs to be preserved between sites. This implies that if $A$ is higher in the least paludified site (e.g., CASO) and lower in the most paludified site (e.g., CAS100), then $g_{\mathrm{s}}$ will adjust in such a way to maintain nearly identical $A / g_{\mathrm{s}}$ ratio, and consequently, iWUE values. Actually, we suspect that this proportional adjustment in the $A / g_{\mathrm{s}}$ ratio might be an important process driving interactions between iWUE and growth rates in a paludified context. As a supporting evidence for this, we found that black spruce tree ring cellulose from the least paludified site (CASO) was significantly 
(a)
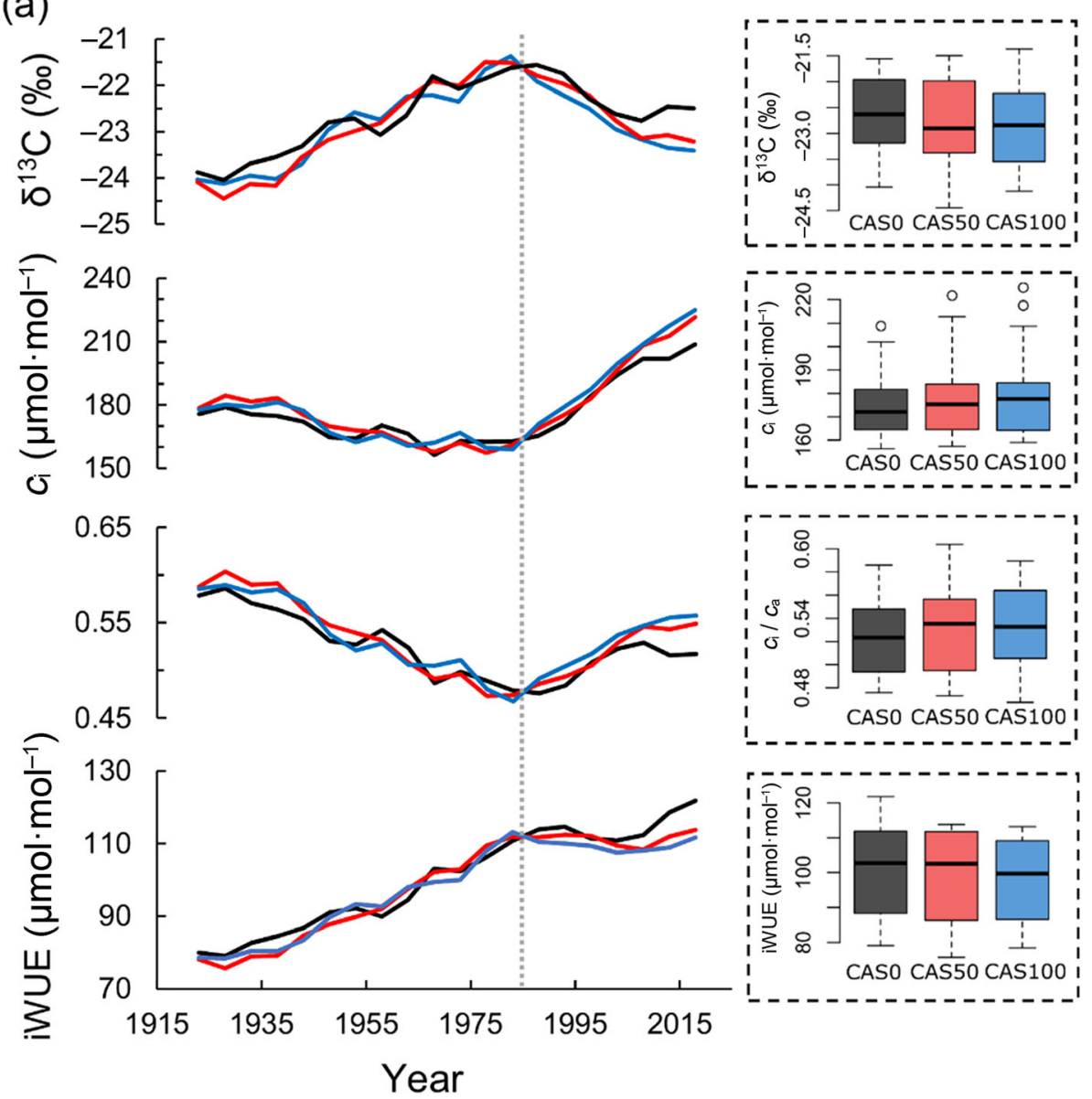

(b)
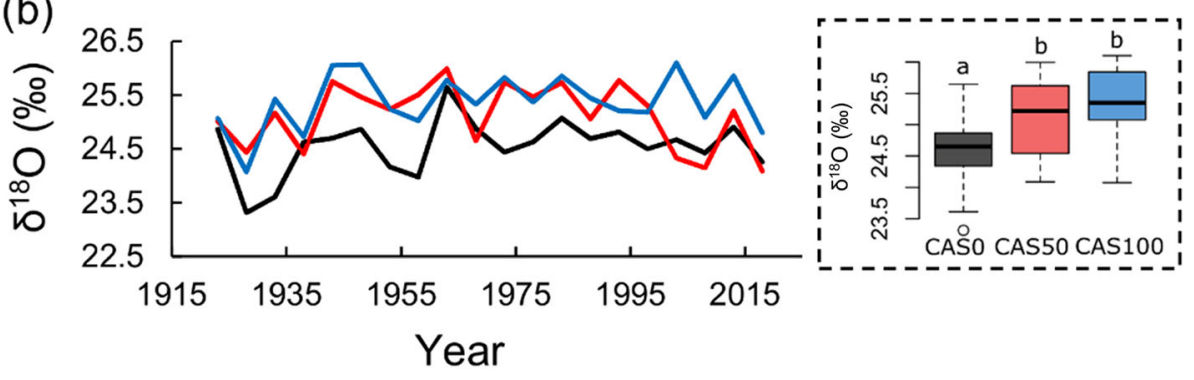

Fig. 4 Black spruce ecophysiological response to rising $c_{\mathrm{i}}$ based on five-year resolution $\delta^{13} \mathrm{C}$ and $\delta^{18} \mathrm{O}$ analyses for the period 1919-2018. a Treering $\delta^{13} \mathrm{C}$ and $\delta^{13} \mathrm{C}$-derived ecophysiological parameter values $\left(c_{i}, c_{i} / c_{a}\right.$, iWUE); $\mathbf{b}$ tree-ring $\delta^{18} \mathrm{O}$ values. Results from CAS0, CAS50, and CAS100 are shown in black, red, and blue, respectively. Boxplots show the median, quartile range, extreme values (dotted lines), and outliers (dots) of the distribution. Different letters above the boxes indicate significant differences between the sites based on Tukey's HSD test (the absence of letters means no significant difference between the three sites). The grey dotted line represents a significant breakpoint $(P<0.01)$ in slopes based on Davies test

more depleted in ${ }^{18} \mathrm{O}$ compared to that of other sites (Fig. 4b). Unsurprisingly, CASO is also the site where radial growth rates are the highest. Increased evapotranspiration rates are probably required to sustain enhanced carbon assimilation and growth rates, forcing $g_{\mathrm{s}}$ to level up and proportionally adjust to increases in $A$ (matching the $A / g_{\mathrm{s}}$ ratio of other sites). Consequently, higher evapotranspiration rates cause black spruce to pump more ${ }^{18} \mathrm{O}$-depleted water from soil depths (Evaristo et al. 2017), which in turn decreases the average $\delta^{18} \mathrm{O}$ of tree ring cellulose. Thus, the slower tree growth rates observed at the most paludified sites seem to result, at least partially, from both lower carbon assimilation rates $(A)$ and stomatal conductance $\left(g_{\mathrm{s}}\right)$.

These findings highlight that processes controlling radial tree growth are decoupled from those that control 


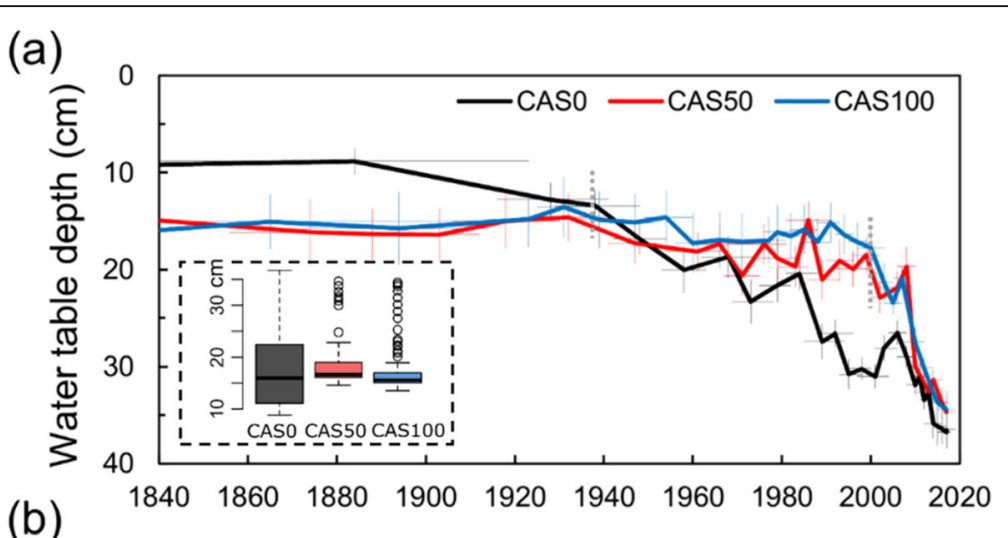

(b)

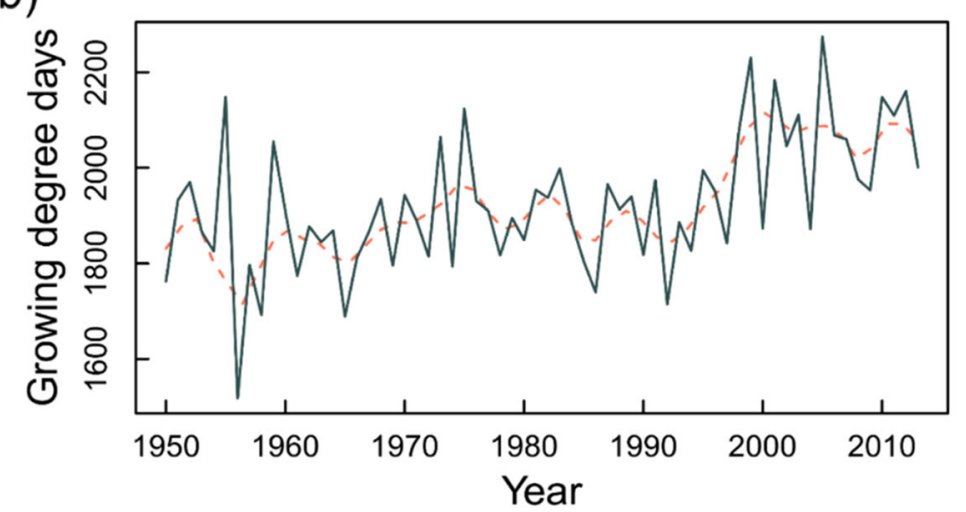

Fig. 5 a WTD reconstructions for the post-fire period based on testate amoeba records and $\mathbf{b}$ growing degree days $\left(>0{ }^{\circ} \mathrm{C}\right)$ from May to September in the study area for the period 1950-2013. Error bars of both WTD reconstructions and age-depth modelling are shown by pale thin lines. Boxplots show the median, quartile range, extreme values (dotted lines), and outliers (dots) of the distribution. Tukey's HSD test indicates no significant difference between the three sites. Grey dotted lines represent significant breakpoints $(P<0.01)$ in slopes based on Davies test. Climate data were extracted from McKenney et al. (2011). A 10-year loess smoothing is shown by the pink dashed line

gas exchanges $\left(A\right.$ and $\left.g_{\mathrm{s}}\right)$, because of tree carbon use and allocation strategies. As an example, many studies performed in non-paludified forests have shown that iWUE increases do not directly translate into enhanced radial growth (e.g., Peñuelas et al. 2011; Lévesque et al. 2014; van der Sleen et al. 2015; Giguère-Croteau et al. 2019). Based on a comparison of tree ring widths and eddycovariance flux towers in boreal Canada, Pappas et al. (2020) showed that aboveground biomass, and most particularly radial stem growth, represents only a minor fraction $(\sim 9 \%)$ of the total gross ecosystem production (GEP). Rocha et al. (2006) also found that stem growth, as estimated from tree ring widths, was not correlated to eddy-covariance-derived GEP in the boreal forest of central Manitoba. These findings point into the same direction: gas exchanges at the vegetation-atmosphere interface are controlled at the leaf level, but the allocation of newly formed photosynthates to either above or belowground compartments may depend on local growing conditions and site-specific growth strategies. Our study can therefore be seen as an extreme case where paludification induced locally-important edaphic changes, strong enough to impact tree carbon allocation strategies. Prioritization of belowground growth may have been more important in the most paludified sites, neglecting carbon allocation to aboveground compartments. This allocation strategy could reinforce tree anchoring (Nicoll et al. 2006) and enhance nutrient uptake (Vicca et al. 2012; Fernández-Martínez et al. 2014), but further research is needed to shed light on the processes driving allocation changes in black spruce trees.

\section{Synchronous changes in iWUE over time}

From the 1920s and until the 1980s, a 40\% iWUE increase was observed at each site, regardless of the accumulated organic layer thickness. This important increase, which occurred over a short period of time, is among the highest recorded; most studies report iWUE increases of $20 \%-30 \%$ over the last century (e.g., Peñuelas et al. 2011; Silva and Horwath 2013; Saurer et al. 2014; Frank et al. 2015; van der Sleen et al. 2015). The increased iWUE resulted from an active response of trees characterized by the maintenance of a relatively constant $c_{\mathrm{i}}$ despite rising $c_{\mathrm{a}}$.

Nevertheless, in the 1980s, tree response to rising $c_{\mathrm{a}}$ suddenly became passive, as shown by the increasing $c_{\mathrm{i}}$ 
and the relatively constant iWUE values at all sites (Fig. 4a). Likewise, a shift to a passive response to increasing $\mathrm{CO}_{2}$ concentration has previously been observed for various tree species in Canada (Giguère-Croteau et al. 2019; Marchand et al. 2020), China (Wang et al. 2012; Wu et al. 2015), and Europe (Waterhouse et al. 2004; Gagen et al. 2011; Linares and Camarero 2012). Three reasons might explain this shift in acclimation strategies. Firstly, this finding possibly indicates reduced carbon assimilation rates $(A)$. Indeed, in such poor growing environments, the photosynthesis apparatus may saturate, and nutrient limitation may downregulate the capacity of trees to assimilate atmospheric carbon (Tognetti et al. 2000; Saurer et al. 2003). Secondly, WTD reconstructions indicate important changes in hydrological conditions over the last 30 years (Fig. 5a) that might have altered black spruce iWUE. The recent water table drawdown could have generated stressful growth conditions since black spruce develops adventitious roots that are generally confined to the upper $20-30 \mathrm{~cm}$ of the organic layer (Lieffers and Rothwell 1987; Viereck and Johnston 1990). However, such a drop in WTD would have most certainly been accompanied by a reduction in stomatal conductance over time, which was not observed here. Moreover, the apparent drying trend could simply reflect an enhanced vertical Sphagnum moss growth, promoted by increasing growing degree days in the last decades (Fig. 5b; Magnan et al. 2018; van Bellen et al. 2018; Primeau and Garneau 2021; Robitaille et al. 2021). The rapid accumulation of organic matter may have exceeded the capacity of adventitious roots to develop higher in the soil profile, compromising the access to oxygen. Lastly, considering that black spruce trees were approximately 180 years old in the 1980 s, we cannot rule out the stand age as another potential cause for the reduction in iWUE (Irvine et al. 2004; Kutsch et al. 2009; Marchand et al. 2020). Further studies are needed to determine which of these factors is mainly responsible for the significant shift observed in tree ecophysiological strategies in the 1980s.

\section{Ecophysiological adjustments to changing conditions}

Changes in local environmental conditions have led to tree ecophysiological adaptations, particularly in the most paludified sites. However, these adjustments in growth mechanisms do not show in tree iWUE. The ratio $A$ to $g_{\text {s }}$ did not differ between sites, despite differences in peat thickness, water table depth, tree rooting depth, canopy cover, and tree growth rates (Tables 1 and 2; Fig. 3 and S2.2). These results indicate that iWUE variations do not reflect tree ecophysiological adjustments induced by changing growing conditions.

Changes in WTD over time (Fig. 5a) did not translate into diverging iWUE trends, in any of the sites.
Although some important environmental factors were not investigated (e.g., nutrients, soil temperature), these results suggest that site-specific conditions were not determinant in iWUE variations. Instead, the synchronous shift in iWUE at each of the three sites in the mid-1980s is best explained by a response to region-wide changes in environmental conditions. Likewise, Pearson correlations calculated between standardized ring-width series and climate variables (monthly temperature and precipitation) indicate a shift in tree response to climate in the 1980s (Supplementary Material 1.1; Fig. S2.8). Black spruce trees became much less sensitive to both temperatures and precipitation after 1980. The reduced sensitivity of trees to temperature since the mid-twentieth century has been reported in previous tree ring studies of northern high-latitude forests, and has been referred to as the "divergence problem" (e.g., Briffa et al. 2004; D'Arrigo et al. 2008; Esper and Frank 2009; Schneider et al. 2014). This "divergence" phenomenon could potentially be caused by thresholded responses or stresses induced by changes in growth conditions (D'Arrigo et al. 2008). While further studies are required to shed light on such trends, these observations could support the hypothesis of photosynthesis apparatus saturation. Indeed, photosynthetic capacity, stimulated by elevated $\mathrm{CO}_{2}$ concentration, may have been limited by the poor growing conditions of forested peatlands, thus stabilizing iWUE and inhibiting stem growth response to temperature.

\section{Conclusions}

In this study, we investigated the mechanisms that are driving tree growth decline in black-spruce-dominated forested peatlands of eastern Canada, by combining dendrochronological, paleoecological, and dendrogeochemical analyses. We attempted, for the first time, to unravel the numerous and complex entanglements between paludification dynamics and forest ecophysiology in these boreal ecosystems. Contrary to our expectations, tree growth decline induced by the paludification process does not result from a reduction of water use efficiency (iWUE). Indeed, we observed no significant differences in iWUE variations between the three study sites, which reflected different degrees of paludification. A substantial increase in iWUE was even recorded at each site for more than 50 years (1925 to 1985). Our tree-ring stable isotope analyses suggest that the decline in forest growth with increasing peat accumulation is rather explained by lower assimilation rates $(A)$, together with lower stomatal conductance $\left(g_{\mathrm{s}}\right)$, and possibly by the prioritization of carbon allocation to belowground components. Moreover, we found no evidence of tree ecophysiological adaptations to variations in water table depth. However, a significant shift in tree ecophysiology 
observed in the 1980s at all sites may suggest that the ratio between assimilation rates and stomatal conductance (iWUE) is influenced by regional or global factors, such as climate or increasing atmospheric $\mathrm{CO}_{2}$ concentration. These findings illustrate the complexity of the interactions between stem growth, ecophysiological processes, and environmental conditions, particularly in paludified sites. These dynamics will need to be further investigated to better predict the response of boreal forested peatlands to future climate change and improve forest management practices.

Our findings warrant further studies of vegetation/forest dynamics models and their application to forested peatlands, as those models are often biased towards converting increases in iWUE into increases in stem growth. Failing to account for paludification-related carbon use and allocation strategies would result in the overestimation of aboveground biomass production in sites where peat accumulation is substantial.

\section{Supplementary Information}

The online version contains supplementary material available at https://doi. org/10.1186/s40663-021-00307-x.

Additional file 1: Supplementary Method. Figure S2.1. Photographs of the Casa forested peatland showing sites CAS100 (top) and CASO (bottom). Figure S2.2. Comparison of the three study sites in terms of peat accumulation, water table depth, tree height and diameter at breast height (DBH). Results of Tukey's test indicate that CAS0 and CAS100 are significantly different for all of these parameters $(P<0.01)$. Different letters above the boxes indicate significant differences between the sites based on Tukey's test. Figure S2.3. Basal area increment distribution between the $25^{\text {th }}$ and the $75^{\text {th }}$ quantiles. Sites CASO, CAS50, and CAS100 are shown in black, red, and blue respectively. The solid line represents the mean annual values of each site. Figure S2.4. Plant macrofossil diagrams of the three peat cores analysed. Data are presented in percentages (silhouettes) and in counts (bars, except for charcoals). The main peat components (\%) are shown in the left column: Sphagnum (green), nonSphagnum mosses (black), ligneous material (brown), Pteridophyte (orange), and Cyperaceae (white). The visual decay index, the dry density of peat, and the water table depth (WTD) reconstructions from testate amoeba assemblages (see figure S2.4) are also presented in the right columns. Figure S2.5. Testate amoeba diagrams. Diagrams show the abundance (\%) of the dominant taxa in the three peat cores analysed. The water table depth (WTD) values inferred from testate amoeba records are presented in the right column (high values indicate dry conditions). Blanks in WTD reconstructions are due to exceptionally low test concentrations in some horizons, where the minimum count (20 tests) was not reached. The main peat components (\%) are shown in the left column: Sphagnum (green), non-Sphagnum mosses (black), ligneous material (brown), Pteridophyte (orange), and Cyperaceae (white). Figure S2.6. March to September climate trends in the study area for the period 1950-2013. (a) precipitation, (b) temperature, and (c) growing degree days $\left(>0^{\circ} \mathrm{C}\right)$. Linear trends are shown by dotted lines. Data were extracted from McKenney et al. (2011). Figure S2.7. Raw tree-ring-width series and standardized ring-width series. Sites CASO, CAS50, and CAS100 are shown in black, red, and blue respectively. Figure S2.8. Pearson correlations between (a) standardized ring-width and monthly temperature, and (b) standardized ring-width and monthly precipitation for the periods 19501980 and 1981-2013. Correlation coefficients were calculated from March to September of the current year and the year preceding ring formation. Months from the previous year of stem growth are marked with an asterisk and significant correlations $(p<0.05)$ are marked with crosses. Results from CASO, CAS50, and CAS100 are shown in black, red, and blue respectively. Table S2.1. Radiocarbon $\left({ }^{14} \mathrm{C}\right.$ ) dates (Beaulne et al. 2021). Supplementary References

\section{Acknowledgements}

We are grateful to Dr. Pierre Grondin (MFFP, Québec) for his precious contribution to this project. Thanks to Nolann Chaumont and Camille Lepage for their help with field and laboratory work. Special thanks to Dr. Nicole Sanderson (Geotop, UQAM) for her help with ${ }^{210} \mathrm{~Pb}$ dating. We also thank Les Tourbeux.ses for their help and useful advice. Thanks to Dr. David Paré (Canadian Forest Service, NRCan) and Dr. Nicolas Bélanger (Université TELUQ) for their comments on an earlier version of the manuscript, and to two anonymous reviewers for their constructive comments that greatly helped improving the manuscript.

\section{Authors' contributions}

All authors designed the research and conducted the fieldwork. J.B. performed the research and É.B., M.G. and G.M. helped analyzing the data. J.B. wrote the first draft of the manuscript and all authors contributed critically to subsequent drafts. The authors read and approved the final manuscript.

\section{Funding}

Scholarships to J.B. were provided by the Natural Sciences and Engineering Research Council of Canada (NSERC-CGS M) and the Fonds de recherche du Québec - Nature et technologies (FRQNT). Fieldwork and analyses were funded by the Natural Sciences and Engineering Research Council of Canada through discovery grants to M.G. and É.B.

\section{Availability of data and materials}

Data will be archived on the Tree-Ring network of Qc-Lab database: http:// dendro-qc-lab.ca.

\section{Declarations}

Ethics approval and consent to participate

Not applicable.

\section{Consent for publication}

Not applicable.

\section{Competing interests}

The authors declare no competing interests.

\section{Author details}

${ }^{1}$ Geotop Research Center, Université du Québec à Montréal, Montréal, Québec H3C 3P8, Canada. ²Department of Geography, Université du Québec à Montréal, Montréal, Québec H3C 3P8, Canada. ${ }^{3}$ GRIL-UQAM, Université du Québec à Montréal, Montréal, Québec H3C 3P8, Canada. ${ }^{4}$ Centre d'études nordiques, Université Laval, Montréal, Québec G1V 0A6, Canada.

Received: 10 August 2020 Accepted: 15 April 2021

Published online: 12 May 2021

\section{References}

Ali AA, Ghaleb B, Garneau M, Asnong H, Loisel J (2008) Recent peat accumulation rates in minerotrophic peatlands of the bay James region, eastern Canada, inferred by ${ }^{210} \mathrm{~Pb}$ and ${ }^{137} \mathrm{Cs}$ radiometric techniques. Appl Radiat Isotopes 66(10):1350-1358. https://doi.org/10.1016/j.apradiso.2008.02.091

Appleby PG, Oldfield F (1978) The calculation of lead-210 dates assuming a constant rate of supply of unsupported ${ }^{210} \mathrm{~Pb}$ to the sediment. Catena 5(1): 1-8. https://doi.org/10.1016/S0341-8162(78)80002-2

Barbour MM (2007) Stable oxygen isotope composition of plant tissue: a review. Funct Plant Biol 34(2):83-94. https://doi.org/10.1071/FP06228

Bartholomeus RP, Witte JPM, van Bodegom PM, van Dam JC, Aerts R (2008) Critical soil conditions for oxygen stress to plant roots: substituting the Feddes-function by a process-based model. J Hydrol 360(1-4):147-165. https://doi.org/10.1016/j.jhydrol.2008.07.029 
Beaulne J, Garneau M, Magnan G, Boucher É (2021) Peat deposits store more carbon than trees in forested peatlands of the boreal biome. Sci Rep 11(1): 2657. https://doi.org/10.1038/s41598-021-82004-x

Beaulne J, Magnan G, Garneau M (2018) Evaluating the potential of testate amoebae as indicators of hydrological conditions in boreal forested peatlands. Ecol Indic 91:386-394. https://doi.org/10.1016/j.ecolind.2018. 01.034

Bégin C, Gingras M, Savard MM, Marion J, Nicault A, Bégin Y (2015) Assessing tree-ring carbon and oxygen stable isotopes for climate reconstruction in the Canadian northeastern boreal forest. Palaeogeogr Palaeocl 423:91-101. https://doi.org/10.1016/j.palaeo.2015.01.021

Belmecheri S, Maxwell RS, Taylor AH, Davis KJ, Freeman KH, Munger WJ (2014) Tree-ring $\delta^{13} \mathrm{C}$ tracks flux tower ecosystem productivity estimates in a NE temperate forest. Environ Res Lett 9(7):074011. https://doi.org/10.1088/17489326/9/7/074011

Bergeron Y, Drapeau P, Gauthier S, Lecomte N (2007) Using knowledge of natural disturbances to support sustainable forest management in the northern Clay Belt. Forest Chron 83(3):326-337. https://doi.org/10.5558/tfc83326-3

Bergeron Y, Gauthier S, Flannigan MD, Kafka V (2004) Fire regimes at the transition between mixedwood and coniferous boreal forest in northwestern Quebec. Ecology 85(7):1916-1932. https://doi.org/10.1890/02-0716

Biondi F, Qeadan F (2008) A theory-driven approach to tree-ring standardization: defining the biological trend from expected basal area increment. Tree-Ring Res 64(2):81-96. https://doi.org/10.3959/2008-6.1

Blaauw M, Christen JA (2019) Rbacon: age-depth Modelling using Bayesian statistics. R package version 2.3.9.1. https://CRAN.R-project.org/package=rba con. Accessed 15 January 2021

Booth RK, Lamentowicz M, Charman DJ (2010) Preparation and analysis of testate amoebae in peatland palaeoenvironmental studies. Mires Peat 7:1-7

Boudreault C, Bergeron Y, Gauthier S, Drapeau P (2002) Bryophyte and lichen communities in mature to old-growth stands in eastern boreal forests of Canada. Can J For Res 32(6):1080-1093. https://doi.org/10.1139/x02-027

Briffa KR, Osborn TJ, Schweingruber FH (2004) Large-scale temperature inferences from tree rings: a review. Glob Planet Chang 40(1-2):11-26. https://doi.org/1 0.1016/S0921-8181(03)00095-X

Bunn A, Korpela M, Biondi F, Campelo F, Mérian P, Qeadan F, Zang C, PuchaCofrep D, Wernicke J (2018) dpIR: dendrochronology program library in R. R package version 1.6.9. https://CRAN.R-project.org/package=dpIR. Accessed 15 January 2021

Cernusak LA, Ubierna N, Winter K, Holtum JAM, Marshall JD, Farquhar GD (2013) Environmental and physiological determinants of carbon isotope discrimination in terrestrial plants. New Phytol 200(4):950-965. https://doi. org/10.1111/nph.12423

Crawford RMM, Jeffree CE, Rees WG (2003) Paludification and forest retreat in northern oceanic environments. Ann Bot 91(2):213-226. https://doi.org/10.1 093/aob/mcf185

D'Arrigo R, Wilson R, Liepert B, Cherubini P (2008) On the 'divergence problem' in northern forests: a review of the tree-ring evidence and possible causes. Glob Planet Chang 60(3-4):289-305. https://doi.org/10.1016/j.gloplacha.2007. 03.004

Davies RB (1987) Hypothesis testing when a nuisance parameter is present only under the alternative. Biometrika 74:33-43

Ehleringer JR, Hall AE, Farquhar GD (1993) Stable isotopes and plant carbonwater relations. Academic Press, New York

Esper J, Frank D (2009) Divergence pitfalls in tree-ring research. Clim Chang 94(34):261-266. https://doi.org/10.1007/s10584-009-9594-2

Evaristo J, McDonnell JJ, Clemens J (2017) Plant source water apportionment using stable isotopes: a comparison of simple linear, two-compartment mixing model approaches. Hydrol Process 31(21):3750-3758. https://doi.org/1 $0.1002 /$ hyp. 11233

Farquhar GD, Ehleringer JR, Hubick KT (1989) Carbon isotope discrimination and photosynthesis. Ann Rev Plant Physiol 40(1):503-537. https://doi.org/10.114 6/annurev.pp.40.060189.002443

Farquhar GD, O'Leary MH, Berry JA (1982) On the relationship between carbon isotope discrimination and the intercellular carbon dioxide concentration in leaves. Aust J Plant Physiol 9:121-137

Farquhar GD, Richards RA (1984) Isotopic composition of plant carbon correlates with water-use efficiency of wheat genotypes. Aust J Plant Physiol 11:539-552

Fenton N, Bergeron Y (2006) Facilitative succession in a boreal bryophyte community driven by changes in available moisture and light. J Veg Sci 17(1):65-76. https://doi.org/10.1111/j.1654-1103.2006.tb02424.x
Fenton N, Lecomte N, Légaré S, Bergeron Y (2005) Paludification in black spruce (Picea mariana) forests of eastern Canada: potential factors and management implications. Forest Ecol Manag 213(1-3):151-159. https://doi.org/10.1016/j. foreco.2005.03.017

Fenton NJ, Simard M, Bergeron Y (2009) Emulating natural disturbances: the role of silviculture in creating even-aged and complex structures in the black spruce boreal forest of eastern North America. J For Res 14(5):258-267. https://doi.org/10.1007/s10310-009-0134-8

Fernández-Martínez M, Vicca S, Janssens IA, Sardans J, Luyssaert S, Campioli M, Chapin FS III, Ciais P, Malhi Y, Obersteiner M, Papale D, Piao SL, Reichstein M, Rodà F, Peñuelas J (2014) Nutrient availability as the key regulator of global forest carbon balance. Nat Clim Chang 4(6):471-476. https://doi.org/10.1038/ nclimate2177

Frank DC, Poulter B, Saurer M, Esper J, Huntingford C, Helle G, Treydte K, Zimmermann NE, Schleser GH, Ahlström A, Ciais P, Friedlingstein P, Levis $S$, Lomas M, Sitch S, Viovy N, Andreu-Hayles L, Bednarz Z, Berninger F, Boettger T, CM D'A, Daux V, Filot M, Grabner M, Gutierrez E, Haupt M, Hilasvuori E, Jungner $\mathrm{H}$, Kalela-Brundin M, Krapiec M, Leuenberger M, Loader NJ, Marah H, Masson-Delmotte V, Pazdur A, Pawelczyk S, Pierre M, Planells O, Pukiene R, Reynolds-Henne CE, Rinne KT, Saracino A, Sonninen E, Stievenard M, Switsur VR, Szczepanek M, Szychowska-Krapiec E, Todaro L, Waterhouse JS, Weigl M (2015) Water-use efficiency and transpiration across European forests during the Anthropocene. Nat Clim Chang 5(6):579-583. https://doi.org/10.1038/ nclimate2614

Gagen M, Finsinger W, Wagner-Cremer F, Mccarroll D, Loader NJ, Robertson I, Jalkanen R, Young G, Kirchhefer A (2011) Evidence of changing intrinsic water-use efficiency under rising atmospheric $\mathrm{CO}_{2}$ concentrations in boreal Fennoscandia from subfossil leaves and tree ring $\delta^{13} \mathrm{C}$ ratios. Glob Change Biol 17(2):1064-1072. https://doi.org/10.1111/j.1365-2486.2010.02273.x

Giardina CP, Ryan MG, Binkley D, Fownes JH (2003) Primary production and carbon allocation in relation to nutrient supply in a tropical experimental forest. Glob Change Biol 9(10):1438-1450. https://doi.org/10.1046/j.1365-24 86.2003.00558.x

Giguère-Croteau C, Boucher É, Bergeron Y, Girardin MP, Drobyshev I, Silva LCR, Hélie J-F, Garneau M (2019) North America's oldest boreal trees are more efficient water users due to increased $\left[\mathrm{CO}_{2}\right]$, but do not grow faster. PNAS 116(7):2749-2754. https://doi.org/10.1073/pnas.1816686116

Göbel L, Coners H, Hertel D, Willinghöfer S, Leuschner C (2019) The role of low soil temperature for photosynthesis and stomatal conductance of three graminoids from different elevations. Front Plan Sci 10:330. https://doi.org/1 0.3389/fpls.2019.00330

Guerrieria R, Belmecheri S, Ollinger SV, Asbjornsen H, Jennings K, Xiao J, Stocker BD, Martin M, Hollinger DY, Bracho-Garillo R, Clark K, Dore S, Kolb T, Munger JW, Novick K, Richardson AD (2019) Disentangling the role of photosynthesis and stomatal conductance on rising forest water-use efficiency. PNAS 116(34):16909-16914. https://doi.org/10.1073/pnas.1905912116

Harper K, Boudreault C, DeGrandpré L, Drapeau P, Gauthier S, Bergeron Y (2003) Structure, composition, and diversity of old-growth black spruce forest of the Clay Belt region in Quebec and Ontario. Environ Rev 11(S1):S79-S98. https:// doi.org/10.1139/a03-013

Husch B, Beers TW, Kershaw JA Jr (2003) Forest mensuration, 4th edn. John Wiley \& Sons, New York

Irvine J, Law BE, Kurpius MR, Anthoni PM, Moore D, Schwarz PA (2004) Agerelated changes in ecosystem structure and function and effects on water and carbon exchange in ponderosa pine. Tree Physiol 24(7):753-763. https:// doi.org/10.1093/treephys/24.7.753

Jeglum JK, Rothwell RL, Berry GJ, Smith GKM (1992) A peat sampler for rapid survey. Frontline, technical note 13 921-932. Canadian forestry service, sault-Sainte-Marie

Juggins S (2017) Rioja: analysis of quaternary science data. R package version 0. 9-15.1. https://cran.r-project.org/package=rioja. Accessed 15 January 2021

Knibbe B (2019) PAST5: personal analysis system for tree ring research version 5.0. 610. Viennes: SCIEM. https://www.sciem.com/products/past/. Accessed 15 January 2021

Korhola A (1995) Holocene climatic variations in southern Finland reconstructed from peat-initiation data. Holocene 5(1):43-58. https://doi.org/10.1177/ 095968369500500106

Kutsch WL, Wirth C, Kattge J, Nöllert S, Herbst M, Kappen L (2009) Ecophysiological characteristics of mature trees and stands - consequences for old-growth forest productivity. In: Wirth C, Gleixner G, Heimann M (eds) Old-growth forests - function, fate and value. Springer-Verlag, Heidelberg. https://doi.org/10.1007/978-3-540-92706-8_4 
Lafleur B, Paré D, Fenton NJ, Bergeron Y (2011) Growth and nutrition of black spruce seedlings in response to disruption of Pleurozium and Sphagnum moss carpets in boreal forested peatlands. Plant Soil 345(1-2):141-153. https://doi.org/10.1007/s11104-011-0767-1

Lamarre A, Magnan G, Garneau M, Boucher É (2013) A testate amoeba-based transfer function for paleohydrological reconstruction from boreal and subarctic peatlands in northeastern Canada. Quatern Int 306:88-96. https:// doi.org/10.1016/j.quaint.2013.05.054

Larson L-A (2016) CooRecorder: image co-ordinate recording, version 8.1.1 Saltsjöbaden: Cybis. https://www.cybis.se. Accessed 15 January 2021

Lavoie M, Paré D, Fenton N, Groot A, Taylor K (2005) Paludification and management of forested peatlands in Canada: a literature review. Environ Rev 13(2):21-50. https://doi.org/10.1139/a05-006

Le Stum-Boivin É, Magnan G, Garneau M, Fenton NJ, Grondin P, Bergeron Y (2019) Spatiotemporal evolution of paludification associated with autogenic and allogenic factors in the black spruce-moss boreal forest of Québec, Canada. Quat Res 91(2):650-664. https://doi.org/10.1017/qua.2 018.101

Lecomte N, Simard M, Bergeron Y (2006) Effects of fire severity and initial tree composition on stand structural development in the coniferous boreal forest of northwestern Québec, Canada. Écoscience 13(2):152-163. https://doi.org/1 0.2980/i1195-6860-13-2-152.1

Lévesque M, Siegwolf R, Saurer M, Eilmann B, Rigling A (2014) Increased wateruse efficiency does not lead to enhanced tree growth under xeric and Mesic conditions. New Phytol 203(1):94-109. https://doi.org/10.1111/nph.12772

Lieffers VJ, Rothwell RL (1987) Rooting of peatland black spruce and tamarack in relation to depth of water table. Can J Bot 65(5):817-821. https://doi.org/1 $0.1139 / \mathrm{b} 87-111$

Linares JC, Camarero JJ (2012) From pattern to process: linking intrinsic water-use efficiency to drought-induced forest decline. Glob Change Biol 18(3):10001015. https://doi.org/10.1111/j.1365-2486.2011.02566.x

Longstreth DJ, Nobel PS (1980) Nutrient influences on leaf photosynthesis: effects of nitrogen, phosphorus, and potassium for Gossypium Hirsutum L. Plant Physiol 65(3):541-543. https://doi.org/10.1104/pp.65.3.541

Magnan G, Garneau M, Le Stum-Boivin É, Grondin P, Bergeron Y (2020) Longterm carbon sequestration in boreal forested peatlands in eastern Canada. Ecosystems 23(7):1481-1493. https://doi.org/10.1007/s10021-020-00483-x

Magnan G, Le Stum-Boivin É, Garneau M, Grondin P, Fenton N, Bergeron Y (2019) Holocene vegetation dynamics and hydrological variability in forested peatlands of the Clay Belt, eastern Canada, reconstructed using a palaeoecological approach. Boreas 48(1):131-146. https://doi.org/10.1111/ bor.12345

Magnan G, van Bellen S, Davies L, Froese D, Garneau M, Mullan-Boudreau G, Zaccone C, Shotyk W (2018) Impact of the little ice age cooling and 20th century climate change on peatland vegetation dynamics in central and northern Alberta using a multi-proxy approach and high-resolution peat chronologies. Quat Sci Rev 185:230-243. https://doi.org/10.1016/j.quascirev.2 018.01.015

Marchand W, Gigardin MP, Hartmann H, Depardieu C, Isabel N, Gauthier S, Boucher É, Bergeron Y (2020) Strong overestimation of water-use efficiency responses to rising $\mathrm{CO}_{2}$ in tree-ring studies. Glob Change Biol 26(8):45384558. https://doi.org/10.1111/gcb.15166

McCarroll D, Loader NJ (2004) Stable isotopes in tree rings. Quat Sci Rev 23(7-8): 771-801. https://doi.org/10.1016/j.quascirev.2003.06.017

McKenney DW, Hutchinson MF, Papadopol P, Lawrence K, Pedlar J, Campbell K, Milewska E, Hopkinson RF, Price D, Owen T (2011) Customized spatial climate models for North America. B Am Meteorol Soc 92:1612-1622

Mitchell EAD, Charman DJ, Warner BG (2008) Testate amoebae analysis in ecological and paleoecological studies of wetlands: past, present and future. Biodivers Conserv 17(9):2115-2137. https://doi.org/10.1007/s10531-007-9221-3

Naulier N, Savard MM, Bégin C, Marion J, Arseneault D, Bégin Y (2014) Carbon and oxygen isotopes of lakeshore black spruce trees in northeastern Canada as proxies for climatic reconstruction. Chem Geol 374-375:7-43

Nicoll BC, Gardiner BA, Rayner B, Peace AJ (2006) Anchorage of coniferous trees in relation to species, soil type, and rooting depth. Can J For Res 36(7):18711883. https://doi.org/10.1139/x06-072

O'Leary MH (1981) Carbon isotope fractionation in plants. Phytochemistry 20(4): 553-567. https://doi.org/10.1016/0031-9422(81)85134-5

Pappas C, Maillet J, Rakowski S, Baltzer JL, Barr AG, Black TA, Fatichi S, Laroque CP, Matheny AM, Roy A, Sonnentag O, Zha T (2020) Aboveground tree growth is a minor and decoupled fraction of boreal forest carbon input.
Agric For Meteorol 290:108030. https://doi.org/10.1016/j.agrformet.2020.1 08030

Payne RJ, Mitchell EAD (2009) How many is enough? Determining optimal count totals for ecological and palaeoecological studies of testate amoebae. J Paleolimnol 42(4):483-495. https://doi.org/10.1007/s10933-008-9299-y

Peñuelas J, Canadell JG, Ogaya R (2011) Increased water-use efficiency during the 20th century did not translate into enhanced tree growth. Glob Ecol Biogeogr 20(4):597-608. https://doi.org/10.1111/j.1466-8238.2010.00608.x

Primeau G, Garneau M (2021) Carbon accumulation in peatlands along a boreal to subarctic transect in eastern Canada. Holocene. doi:https://doi.org/10.11 77/0959683620988031, 095968362098803

R Core Team (2018) R: a language and environment for statistical computing, version 3.5.5. Viennes: R Foundation for Statistical Computing. https://www.rproject.org/. Accessed 15 January 2021

Reimer PJ, Bard E, Bayliss A, Beck JW, Blackwell PG, Bronk Ramsey C, Buck CE, Cheng H, Edwards RL, Friedrich M, Grootes PM, Guilderson TP, Haflidason H, Hajdas I, Hatté C, Heaton TJ, Hoffmann DL, Hogg AG, Hughen KA, Kraiser KF, Kromer B, Manning SW, Niu M, Reimer RW, Richards DA, Scott EM, Southon JR, Staff RA, Turney CSM, van der Plicht J (2013) IntCal13 and Marine13 radiocarbon age calibration curves 0-50000 years cal BP. Radiocarbon 55(4): 1869-1887. https://doi.org/10.2458/azu_js_rc.55.16947

Robitaille M, Garneau M, van Bellen S, Sanderson NK (2021) Long-term and recent ecohydrological dynamics of patterned peatlands in north-Central Quebec (Canada). Holocene. doi:https://doi.org/10.1177/0959683620988051, 095968362098805

Rocha AV, Goulden ML, Dunn AL, Wofsy SC (2006) On linking interannual tree ring variability with observations of whole-forest $\mathrm{CO}_{2}$ flux. Glob Change Biol 12(8):1378-1389. https://doi.org/10.1111/j.1365-2486.2006.01179.x

Ruppel M, Väliranta M, Virtanen T, Korhola A (2013) Postglacial spatiotemporal peatland initiation and lateral expansion dynamics in North America and northern Europe. Holocene 23(11):1596-1606. https://doi.org/10.1177/ 0959683613499053

Saucier J-P, Robitaille A, Grondin P (2009) Cadre bioclimatique du Québec. In: Doucet R, Côté M (eds) Manuel de foresterie, 2nd edn. Éditions MultiMondes, Québec

Saurer M, Cherubini P, Bonani G, Siegwolf R (2003) Tracing carbon uptake from a natural $\mathrm{CO}_{2}$ spring into tree rings: an isotope approach. Tree Physiol 23(14): 997-1004. https://doi.org/10.1093/treephys/23.14.997

Saurer M, Spahni R, Frank DC, Joos F, Leuenberger M, Loader NJ, McCarroll D, Gagen M, Poulter B, Siegwolf RTW, Andreu-Hayles L, Boettger T, DoradoLiñán I, Fairchild IJ, Friedrich M, Gutierrez E, Haupt M, Hilasvuori E, Heinrich I, Helle G, Grudd H, Jalkanen R, Levanič T, Linderholm HW, Robertson I, Sonninen E, Treydte K, Waterhouse JS, Woodley EJ, Wynn PM, Young GHF (2014) Spatial variability and temporal trends in water-use efficiency of European forests. Glob Change Biol 20(12):3700-3712. https://doi.org/1 $0.1111 /$ gcb. 12717

Scheidegger Y, Saurer M, Bahn M, Siegwolf R (2000) Linking stable oxygen and carbon isotopes with stomatal conductance and photosynthetic capacity: a conceptual model. Oecologia 125(3):350-357. https://doi.org/10.1007/s00442 0000466

Schneider L, Esper J, Timonen M, Büntgen U (2014) Detection and evaluation of an early divergence problem in northern Fennoscandian tree-ring data. Oikos 123(5):559-566. https://doi.org/10.1111/j.1600-0706.2013.00836.x

Silva LCR, Horwath WR (2013) Explaining global increases in water use efficiency: why have we overestimated responses to rising atmospheric $\mathrm{CO}_{2}$ in natural forest ecosystems? PLoS One 8(1):e53089. https://doi.org/10.1371/journal. pone.0053089

Simard M, Lecomte N, Bergeron Y, Bernier PY, Paré D (2007) Forest productivity decline caused by successional paludification of boreal soils. Ecol Appl 17(6): 1619-1637. 10.189e0/06-1795.1

Tognetti T, Cherubini P, Innes $J$ (2000) Comparative stem-growth rates of Mediterranean trees under background and naturally enhanced ambient $\mathrm{CO}_{2}$ concentrations. New Phytol 146(1):59-74. https://doi.org/10.1046/j.1469-813 7.2000.00620.x

Ung CH, Bernier P, Guo XJ (2008) Canadian national biomass equations: new parameter estimates that include British Columbia data. Can J For Res 38(5): 1123-1132. https://doi.org/10.1139/X07-224

van Bellen S, Magnan G, Davies L, Froese D, Mullan-Boudreau G, Zaccone C, Garneau M, Shotyk W (2018) Testate amoeba records indicate regional 20thcentury lowering of water tables in ombrotrophic peatlands in CentralNorthern Alberta, Canada. Glob Change Biol 24(7):2758-2774. https://doi. org/10.1111/gcb.14143 
van Cleve K, Dyrness CT, Viereck LA, Fox J, Chapin FS, Oechel W (1983) Taiga ecosystems in interior Alaska. BioScience 33(1):39-44. https://doi.org/10.23 $07 / 1309243$

van der Sleen P, Groenendijk P, Vlam M, Anten NPR, Boom A, Bongers F, Pons TL, Terburg G, Zuidema PA (2015) No growth stimulation of tropical trees by 150 years of $\mathrm{CO}_{2}$ fertilization but water-use efficiency increased. Nat Geosci 8(1):24-28. https://doi.org/10.1038/ngeo2313

Vicca S, Luyssaert S, Peñuelas J, Campioli M, Chapin FS III, Ciais P, Heinemeyer A, Högberg P, Kutsch WL, Law BE, Malhi Y, Papale D, Piao SL, Reichstein M, Schulze ED, Janssens IA (2012) Fertile forests produce biomass more efficiently. Ecol Lett 15(6):520-526. https://doi.org/10.1111/j.1461-0248.2012. 01775.x

Viereck LA, Johnston WF (1990) Picea mariana (Mill.) B.S.P. In: Burns RM, Honkala BH (eds) Silvics of North America: 1. Conifers. US Department of Agriculture. Forest Service, Washington

Vincent J-S, Hardy L (1977) L'évolution et l'extension des lacs glaciaires Barlow et Ojibway en territoire québécois. Géo Phy Quat 31:357-372

Voelker SL, Brooks JR, Meinzer FC, Anderson R, Bader MKF, Battipaglia G, Becklin KM, Beerling D, Bert D, Betancourt JL, Dawson TE, Domec J-C, Guyette RP, Körner C, Leavitt SW, Linder S, Marshall JD, Mildner M, Ogée J, Panyushkina I, Plumpton HJ, Pregitzer KS, Saurer M, Smith AR, Siegwolf RTW, Stambaugh MC, Talhelm AF, Tardif JC, Van de Water PK, Ward JK, Wingate L (2016) A dynamic leaf gas-exchange strategy is conserved in woody plants under changing ambient $\mathrm{CO}_{2}$ : evidence from carbon isotope discrimination in paleo and $\mathrm{CO}_{2}$ enrichment studies. Glob Change Biol 22(2):889-902. https:// doi.org/10.1111/gcb.13102

Wang W, Liu X, An W, Xu G, Zeng X (2012) Increased intrinsic water-use efficiency during a period with persistent decreased tree radial growth in northwestern China: causes and implications. Forest Ecol Manag 275:14-22. https://doi.org/10.1016/j.foreco.2012.02.027

Waterhouse JS, Switsur VR, Barker AC, Carter AHC, Hemming DL, Loader NJ, Robertson I (2004) Northern European trees show a progressively diminishing response to increasing atmospheric carbon dioxide concentrations. Quat Sci Rev 23(7-8):803-810. https://doi.org/10.1016/j.qua scirev.2003.06.011

Wu G, Liu X, Chen T, Xu G, Wang W, Zeng X, Zhang X (2015) Elevationdependent variations of tree growth and intrinsic water-use efficiency in Schrenk spruce (Picea schrenkiana) in the western Tianshan Mountains, China. Front Plant Sci 6:309

Yakir D (1992) Variations in the natural abundance of oxygen-18 and deuterium in plant carbohydrates. Plant Cell Environ 15(9):1005-1020. https://doi.org/1 0.1111/j.1365-3040.1992.tb01652.x

\section{Submit your manuscript to a SpringerOpen ${ }^{\oplus}$ journal and benefit from:}

- Convenient online submission

- Rigorous peer review

- Open access: articles freely available online

- High visibility within the field

- Retaining the copyright to your article

Submit your next manuscript at $\boldsymbol{\nabla}$ springeropen.com 